\title{
PERCEPTIONS OF RELATIONSHIP VIOLENCE: A YOUTH PERSPECTIVE
}

\section{BML Pretorius, SS Terblanche, JL Tshiwula}

\section{INTRODUCTION}

Youths constitute a significant and growing sector of the population living in South Africa. Dickson-Tetteh and Ladha (2000:2) state that there are currently about 18 million people under the age of 20 years, who constitute $44 \%$ of the total population. McWhirter, McWhirter, McWhirter and McWhirter (2004:4) suggest that the well-being and stability of society depend on our ability to prepare well-adjusted and responsible young people to step forward to take up their roles as the older generation passes. In contemporary society the youth face a host of challenges that can impact either positively or negatively on their ability to negotiate the transition from childhood to adulthood. During adolescence youths complete crucial life-tasks and as such are especially vulnerable to the effects of violence as both perpetrators and victims.

Violence is a social phenomenon that is endemic within both developed and developing countries. Given the specific historical and contextual realities of South Africa, the term "culture of violence" has been coined, which reflects concerns about the unacceptably high incidence of violence in our society. Research has found that exposure to and experience of violence is frequently associated with vulnerability to mental health problems and with heightened risk for committing violent actions and other risk behaviours by adolescents. Furthermore, where violence is perceived to be endogenous rather than accidental or an aberration, the consequences are suggested to be more far reaching (Berthold, 2000:19). The National Youth Policy (National Youth Commission, 2000:15, 27) acknowledges the need to reduce violence committed by and towards young men and women as one of the most significant challenges facing South Africa today. The main critique levelled at a significant proportion of life-skills and other programmes that have attempted to address the prevention or reduction of violence has been that they represent the worldviews of adults (and not youths) regarding specific youth concerns or issues. This gap was identified by the Research Resource Centre, CSIR (2000:1) and thus the need for research was highlighted in the area of youth perceptions of violence that would add to the understanding of youth in their social contexts in order to develop informed interventions. Much of the current data are drawn from crime statistics and quantitative research. This sentiment is reflected in current government policy, which advocates strongly that the voices of youths and children should be heard in the formulation of policies and programmes that address their needs (National Youth Commission, 2000; African Charter on the Rights of the Child, 1990; United Nations Convention on the Rights of the Child, 1989).

This article privileges a youth perspective regarding perceptions of relationship violence based on the findings of a qualitative research study. The study sought to enhance a professional understanding of youths, focusing on their representations of relationship violence in their social contexts, in order to contribute towards preventive intervention that is informed by the youths themselves.

In the ensuing sections a brief overview of the research methodology is presented, the themes and sub-themes are discussed and verified with reference to the literature, and finally closing 
remarks are presented in the form of the central storyline as a youth perspective to guide recommendations for relationship violence prevention.

\section{RESEARCH METHODOLOGY}

This section presents a brief description of the methodology implemented in the actualisation of the qualitative phase of the broader research process within a three-phase study. The objective that guided this qualitative research endeavour can be stated as follows: to explore and describe the perceptions and experiences of youths regarding violence in relationships over the course of their life histories. This article represents one of the themes emanating from this broader study, namely the perceptions of youths regarding relationship violence. The qualitative phase of the study employed an exploratory, descriptive and contextual design. The essence of this phase of the research study is "the idea of acquiring an 'inside' understanding - the actors' definitions of the situation", which according to Schwandt (2001:102) is the central concept for understanding the purpose of qualitative inquiry. "Qualitative inquiry is particularly orientated toward exploration, discovery, and inductive logic. The strategy of inductive designs is to allow the important analysis dimensions to emerge from patterns found in the cases under study without presupposing in advance what the important dimensions will be" (Patton, 2002:55, 56).

Within the aforementioned research design, the auto/biographical narrative (Roberts, 2002) was utilised as the strategy of inquiry to garner narratives from 58 youths who voluntarily participated in the study. The paradigm of qualitative inquiry is generally associated with "going into the field". However, Patton (2002:49) emphasises that this is not the only legitimate way to understand human behaviour. The author emphasises that "for certain questions and for situations involving large groups, distance is inevitable, perhaps even helpful". The latter was considered to be applicable to the study under review in view of the number of participants involved in the study and because of the fact that the participants are youths. Miller and Glassner (1997:101-102) alert us to the difference in meaning systems between adults and adolescents or youths, and the unique challenge this presents in research. Given also the potential sensitivity of the research topic, namely experiences with violence, the focus group and individual interview methods were seen as potentially problematic or contentious from an ethical point of view. For the reasons outlined, the decision was made to implement the biographical narrative mode of inquiry. Quoting Denzin (1989a), Creswell (1998:231) offers the following definition of this type of inquiry: "The biographical study is the study of a single individual and his or her experiences as told to the researcher or as found in documents and archival materials". Muller (in Crabtree \& Miller, 1999:221) describes narratives as "stories that relate the unfolding of events, human action, or human suffering from the perspective of an individual's lived experience". Patton (2002:115) similarly asserts that narrative studies place the "emphasis on understanding lived experience and perceptions of experience".

A non-probability, purposive sample was drawn from amongst youths attending a high school (senior secondary school) or a tertiary education institution in the area of the Nelson Mandela Metropole. The sampling strategies utilised to reach the specified group of participants for the research study included a combination of convenience, opportunistic and snowball or chain sampling (Marshall \& Rossman, 1999:78; Creswell, 1998:119; Schurink in De Vos, 1998:254). 
Data from participants' individual narratives were analysed in congruence with the purpose of interpretive analysis which is, according to Terre Blanche and Kelly, "to provide 'thick description' of the characteristics, processes, transactions and contexts that constitute the phenomenon, as well as an account of the researcher's role in constructing this description" (Terre Blanche \& Durrheim, 1999:139; Schwandt, 2001:110). This initial step in the dataanalysis process consisted of a content or thematic analysis of the auto/biographical narratives and resulted in the identification of themes, sub-themes and categories (Terre Blanche \& Durrheim, 1999:140-144; Roberts, 2002:121). These data were in turn subjected to a literature control, which enabled a process of verification against the existing body of knowledge. This allowed for the data to be compared and contrasted with what is known and to discover what local or substantive theory emerges in terms of the specific context that is the focus of this study (Strauss \& Corbin, 1998:22; Schwandt, 2001:110; Charmaz as cited in Denzin \& Lincoln, 2003:249).

In the following discussion the theme perceptions of youth of relationship violence, together with its sub-themes and categories, will be presented. This discussion will be supported with direct representative quotations from the narratives of the participants as a means of giving voice to the unique meaning ascribed to the phenomenon of violence as it has featured in the life stories of youth who participated in this study. Mullender, Hague, Kelly, Malos, \& Regan (2002:3) contend that "we now understand that adult representations and interpretations of children's lives might say more about the observer than the observed". For this very reason "it has been seen as essential to convey children's own accounts at first hand - to include their voices". Hence, the discussion includes excerpts from the narratives submitted by the youths.

It should be noted that the quotations are presented verbatim from the narratives of the youths and are therefore not always grammatically correct. No names are given in order to protect the identity of participants.

\section{DEFINING VIOLENCE AND RELATIONSHIP VIOLENCE}

Arriving at a definition of violence is problematic as it is a social construct and therefore, is ascribed a range of meanings by different individuals or groups in various contexts. In approaching this study a definition of the concepts "violence" or "relationship violence" was not imposed on participants. Instead, during the data-collection phase an open-ended invitation was extended to participants to respond to the following stimulus request:

Write a story/essay in which you express/share your personal thoughts and views about how violence has featured in your life story and/or in the life of youth around you. You can think about this in terms of the relationships in which you are involved in the different areas of your life, for example, at home - for instance with family members, relatives and so on; at school, and in the other areas of your life and in the relationships of other youths.

It became evident during the phase of data analysis that youths expressed clear perceptions or views regarding the range of forms of violence, and they cited or labelled clear examples of physical, emotional, verbal and economic abuse. This relates to the sense that developed where it appeared that participants seem to be aware of being "abused" or of their rights having been "violated". What also became apparent from the narratives of participants regarding their definition of violence is that youths tended to use the concepts "abuse" and "violence" interchangeably. 


\section{DISCUSSION OF FINDINGS}

In the ensuing section a profile of the participants precedes the discussion of the theme "perceptions of youth regarding relationship violence", which is presented in relation to the five sub-themes as they emerged during the process of data analysis of the 58 youth narratives.

\section{THEME: Perceptions of youth regarding relationship violence}

The Oxford Advanced Learner's Dictionary (1995) defines "perception" as the ability to see, hear or understand things; awareness; a deeper natural understanding and awareness than is usual; a way of seeing, understanding or interpreting something. The dictionary definition of the verb "perceive" as a process involving the senses is consistent with the view expressed by Mohr and Fantuzzo (2000:73) that "all human experience is filtered by the senses". Sweatt, Harding, Knight-Lynn, Rasheed and Carter (2002:109, 110) make a distinction between experience and exposure to violence either as a witness, victim or having knowledge of others' victimisation. Linking the aforementioned perspectives to the dictionary definitions, it would appear that the perceptions of youths regarding violence can be regarded as their "world-view" or "frame of reference" as shaped by the awareness, insight or understanding gained through being either directly a victim of violence or as a witness or having knowledge of another person's victimisation. The two latter situations could be regarded as indirect, vicarious or secondary. The narratives of participants related stories of perceptions and experiences as direct victims, as observers or witnesses, or having knowledge of different forms of victimisation.

The perceptions of youths regarding violence were expressed in the following sub-themes: violence is part of the tapestry of everyday life; violence occurs in an unclear normative space; violence is about unexpressed feelings; violence is not a solution but a senseless act; violence is destroying the world; and violence has a gender and a power bias. What must be emphasised at this point is that the perceptions of participants about violence were also integrally linked with their experiences.

In order to present a composite yet brief overview of the theme "perceptions of youth regarding relationship violence" with its identified sub-themes and categories a tabular representation is presented below. 


\begin{tabular}{|c|c|c|}
\hline THEME & SUB-THEMES & CATEGORIES \\
\hline $\begin{array}{l}\text { Perceptions of } \\
\text { youth regarding } \\
\text { relationship } \\
\text { violence }\end{array}$ & $\begin{array}{l}\text { 1. Violence is part of the tapestry } \\
\text { of everyday life } \\
\text { 2. Violence occurs in an unclear } \\
\text { normative space } \\
\text { 3. Violence is about unexpressed } \\
\text { feelings } \\
\text { 4. Violence is not a solution but a } \\
\text { senseless act } \\
\text { 5. Violence is destroying the world } \\
\text { 6. Violence has a gender and a } \\
\text { power bias }\end{array}$ & $\begin{array}{l}\text { 1.1 Family or home environment } \\
\text { 1.2 School } \\
\text { 1.3 Media } \\
\text { 1.4 Entertainment } \\
\text { 1.5 Friends/peers } \\
\text { 1.6 Community } \\
\text { 4.1 People lack skills in } \\
\text { managing conflict in their } \\
\text { relationships } \\
\text { 4.2 There is a tendency to treat } \\
\text { violence with violence } \\
\text { 5.1 Violence destroys people's } \\
\text { lives } \\
\text { 5.2 Violence affects the economy } \\
\text { of a country } \\
\text { 6.1 Men treat women as } \\
\text { possessions } \\
\text { 6.2 Women tend to take the blame } \\
\text { for the violence } \\
\text { 6.3 Violence is about control } \\
6.4 \text { Women provoke the violence }\end{array}$ \\
\hline
\end{tabular}

A discussion of the six sub-themes will be presented with their relevant categories as they were induced from the data contained in the youth narratives during the process of data analysis.

\section{Sub-theme: Youth perceive relationship violence as part of the tapestry of everyday life}

The word pictures painted by participants in their narratives seemed to suggest that violence has permeated every facet of their lives on a day-to-day basis. Participants' narratives evidenced descriptions of the various forms of violence or abuse that form part of their context, for example, child abuse, domestic or family violence, crime, sexual abuse with its sub-types or categories. The following quotations reflect the sentiments of participants that violence is part of the everyday tapestry of life:

"Violence has been a part of this world for over thousands of years, which is actually a bad thing."

"It doesn't matter where you live or how old you are. Everywhere you go there will be violence."

"Violence is all around us and we can do nothing about it."

"Violence is the acid that poisons our childhood."

"Violence is a driving force that happens in our country. I think it is everywhere."

"Violence is something we all have to deal with at some time or the other." 
"In my community violence was everyday life ..."

"In ons allerdaagse lewe sien ons geweld orals op die TV, by die huis, selfs in die openbare publiek."

"Many people have to cope with violence as a normal part of their everyday lives."

"I think that violence is something that always appears in our lives."

"Everybody is doing violence from children to adults; it's uncontrollable."

The majority of participants described how they perceive violence to be a feature of the day-today lifestyle of people in families, in the school environment where violence is part of the interaction between friends/peers, in the media and entertainment; and violence occurs in the community context in the guise of crime and racism. Goldstein (1994:15) argues that "aggression occurs in an immediate, often circumscribed, largely identifiable location", which he terms the site. Such sites include the home, the school, the neighbourhood and the wider community context. The view articulated by Goldstein (1994) supports the perceptions expressed by participants in their narratives and are represented as the categories which support this specific sub-theme. The following section will explore briefly the family or home environment as a site identified by youth for abuse and violence.

\section{Category: Relationship violence in context of the family or home environment}

John Bradshaw in the foreword to Crawford (1994:ix) asserts the most violent place is the family. The significance of the family environment, according to Goldstein (1994:15), cannot be underestimated. The author portends that the home is much more than just a physical structure. Rather, home is:

- Order: the patterning of environmental experience;

- Orientation: in space, time and society;

- Identity: implies a bonding of place and person;

- Connectedness: with place and temporally, with the past, the present and the future;

- Ritual: a place of repeatable and cyclical activities and events;

- Social rules and social relationships;

- Affordances: the positive meanings and behaviours which an environment may facilitate; and

- Impedances: the negative meanings and behaviours which an environment may facilitate.

The above observations point to the centrality of the role of the family in the lives of human beings and more specifically in the lives of children. The narratives of participants were dominated by the centrality of the family environment in the unfolding acts of violence. Davies, Harold, Goeke-Morey and Cummings (2002:1) highlight the fact that "witnessing conflict between parents is a normal part of family life for children". However, children are at risk for suffering adverse psychological consequences as bystanders to their parents' relationship difficulties when abuse or violence is involved and when conflict remains unresolved.

The excerpts from the narratives that represent the perceptions of participants of violence in the family or home context are as follows:

"Teenagers are very vulnerable people ... then they still have to cope with domestic violence." 
"There are all sorts of violence; men abuse women, women abuse men, and fathers who abuse their kids."

"My parents would argue and on occasions my dad would hit my mom or throw an object at her.”

"From a young age I have grown up with violence all around me. For one the television, on the news and on programmes, and the radio and in my own home."

"Violence is an everyday part of their lives in their family ...."

\section{Category: Perceptions of the school environment as a context for relationship violence}

As previously stated the school is identified as one of the sites where violence occurs and supports participants' perceptions that violence is part of the tapestry of everyday life. Goldstein (1994:34) contends that for decades school was believed to be neutral turf, but emphasises that this is not true as "the street comes to the school". This statement points also to the interrelatedness of the various sites and we, as professionals, would do well to bear this in mind when seeking to expand our understanding of a social phenomenon such as violence.

Huesmann (1994:8) lists the school as one of the varying contexts beside the family, peer groups and the community in which violence and aggression are learned and perpetrated. For the purpose of this specific discussion, the peer group and the school context are combined, because the narratives of participants appeared to suggest that peers, within the school environment, create a particular "climate". Prilleltensky, Nelson and Peirson (2001:110-111) argue that there is "no one community institution that plays a larger role in the lives of children and youth than school, a place where they spend a great amount of time, where they learn and where they socialise".

Within this category, participants described that the predominant form of violence that manifests in the school environment is physical fighting. The following quotations attest to this perception:

"At [...] High School I was always getting into trouble for fighting with the boys."

"A girl at [...] High School wanted to fight with me. It seems like it was all about jealousy."

"Since I was in Grade 4 I began to experience violence. I always fight with a boy and my best friend all the time."

"In my high school there's a lot of violence among students. There are always fights."

"I am staying in the hostel and we get in fights all the time, but mostly we argue a lot."

"Violence has featured a lot in my life through things like fighting with close friends, fighting with my enemies..."

Besides physical fighting, emotional abuse was also described:

“' $n$ Verdere kennismaking met geweld was toe ek in Gr 7 was en een dogter 'n ander deur die gesig geslaan het. Ek het ook met emosionele geweld te doen gehad omdat daar 'n paar arrogante seuns in ons Gr 7 klas was wat emosionele geweld teenoor die onderwysers geopenbaar het. Die seuns het geweet dat daar niks met hulle sal gebeur nie en daarom het hulle almal 'ge-rule'. Hulle was gedurig op die speelgronde in 'n bakleiery betrokke."

"At primary school there was this girl that was always beaten by this other group of boys. They would pick on her even if she did nothing."

The following selected quotations highlight that violence is connected to the image of youths in relation to their peers. 
"I think in school that's where the demon of violence is worse because we want to be more famous. You fight for a simple thing."

"It is very sad to see how young people are involved with violence. They always hang out with the wrong people. The way young people are always trying to do things to impress their friends."

"Many scholars commit violence so that their friends can think they are the best and nobody will mess with them, they are the best and nobody is better than them."

"The second is from their schools that everybody tries to be like someone."

"I think a big group of the boys wanted to stop, but were afraid of being called a coward, and because of peer pressure, no one spoke up about it."

The phenomenon of "bullying" in the school environment was introduced into the narratives as follows:

"Op die dag van 23 Maart het ek as omstander, gestaan en toekyk, hoe dat skoolseuns 'n ander een se hare skeer met 'n skêr. ... Ek het vasgestaan en toekyk hoe 'n groep seuns op mekaar geval het. Een het geskree asof ' $n$ moord op hom iutgevoer word. Niemand het aandag aan 'n nood skree gegee. ... Alles was na 'n ruk doodstil. Die groep seuns het in verskillende rigtings gespat. ... Soos verloop van die dag is navrae gedoen oor die voorval. Die volgende oomblik was alles nog onduidelik en poliesiemanne en -vroue was orals op die perseel sigbaar. ... Die volgende dag is dit aangekondig dat die seun se hare was so geskeur dat dit eintlik sy kopvel duidelik sigbaar was en vol bloed."

"I only found out now that they that they beat her because they thought she was beautiful and they wanted her to be their girlfriend, but they were too afraid to ask her out so to cover that fear they will pick on her."

\section{Category: Perceptions of role of media in relationship violence}

The influence of the media has been the subject of considerable debate and research. The specific contribution of the media to shaping the attitudes and behaviour of individuals is important given the present-day reality highlighted by Potter (1998:25) that "we truly live in a media-saturated culture". Gunther and Wober (1988:1), writing from the perspective of researchers at the Independent Broadcasting Authority in Britain, assert "from the earliest days of television there has been concern about the portrayal of violence in programmes". Potter (1998:165) concurs with the view of Brants, Hermes and Van Zoonen (1998:141-142) that one of the most popular plot types on television revolves around violence, because it serves "the function of arousing the audience and getting viewers interested in the action". Potter highlights that amongst the themes favoured is the one that "the world is a mean and risky place". In the context of this study this is a significant statement as this theme links to the perceptions of youths discussed earlier that violence is part of everyday life.

In their narratives the youths make reference to the following types of media: electronic television, video games and movies; print media - comics and newspapers. The youths appeared to draw a direct link between the viewing of violent behaviour on television and the enactment and mimicking of such behaviour by youths. This is evidenced in the following quotations:

"They had probably seen people attacking each other in fictional television programmes and thought that was how everyone solved their problems." 
"I think all violence began from watching television programmes that people should not."

"My eerste kennismaking met geweld was met goed wat ek op die televisie gesien het."

"I watched a program on reality TV. It was for me a big shock when I saw the violence on the $T V . "$

"Die televisie is 'n medium wat geweld aanblaas."

"I honestly get cross when I turn on the television/radio on and all you hear is violence."

"TV has one of the most effects on children."

"I think they mustn't show all those violent things on TV, cause children see it and think it's the right thing to do or it is the way to fame."

"The one main cause for violence is the media because they influence our lifestyles. We want to be just like celebrities."

\section{Category: Relationship violence in context of entertainment}

It is acknowledged that entertainment in the form of films and video games can be categorised as falling within the broader category of media. The decision was taken, however, to place these in a category of entertainment or leisure activities to signify the specific connotation read within the data set. Furthermore, within the life-stage being negotiated by youths entertainment or leisure is a significant feature. According to Perry, Kelder and Komro (in Millstein, Petersen \& Nightingale., 1993:82), "television, films, rock music, videos, and even novels increasingly provide images, messages and role models for violent behaviour". Brants et al. (1998:140) point out that movies/films and popular video-games have also followed the trend of other media forms by "cashing in on violence". The authors highlight the fact that each sequel of a film that is made sees the "hero" claim more lives. One such example quoted is Robocop 1 in which 32 victims were claimed and in the sequel Robocop 2, 81 people were killed. What makes this example especially pertinent in the context of this study is the reality voiced by participants of "double standards" or "unclear values about violence". The violence in the stated example is violence perpetrated in the name of law and order and, thus, sends the message that violence is condoned in some situations. Participants refer to the role that entertainment or leisure activities have played in perpetuating violence in our society in the following manner:

"That artist EMINEM - his music is just violence. What kind of role model is he?"

"I think in general boys are more violent because of the games they play and because they like action/violent movies or TV shows. They identify with the 'hero' role/character, who is perceived as a tough, strong, violent character who 'always gets the girl'."

"In high school, however, there was a troubling trend growing under the boys in my class in Gr 10. They watched a movie called 'Fight Club' about a group of depressed young men who join a club where they beat up other men to release themselves from inner turmoil and suppressed anger. ... The movie featured Brad Pitt, who I believe also played a role, because he was the 'hero'. The boys decided to form their own 'Fight Club'."

"Even in comics nowadays they shoot each other and throw bombs, etc."

\section{Category: Perceptions of relationship violence in the community context}

It would seem appropriate that several authors make a distinction between the immediate environment in which the individual or a family resides (the neighbourhood) and the wider community or societal context. Although the two systems are interrelated, there are instances where specific circumstances may prevail in the neighbourhood contexts that are not 
necessarily generalisable to the wider societal context. Prilleltensky et al. (2001:72) intimate that child abuse and other forms of violence are a symptom not only of individual or family trouble, but community trouble as well. Some of the vulnerabilities that the authors refer to are poverty, lack of community resources, inadequate or poor housing, lack of social cohesion and social isolation. The aspects that seemed to encapsulate the perceptions of youths regarding violence in this respect were the issues of crime and racism. These two phenomena were perceived by participants in this study to occur in both the neighbourhood and the wider community context. The dominant feature of the narratives was the focus on crime and the different voice in this instance was a focus on racism.

The narratives of participants appeared to suggest that crime featured for them as both a cognitive perception as well as direct experience. Below are selected quotations that illustrate these two levels of awareness:

"Almost every night there would be 3-6 gunshots."

"Violence and crime is a very serious thing, because if you are brought up in a ruff neighbourhood, that could decide what kind of a person you will be one day."

"I began to experience violence in about the last year of primary school when my grandpa was mugged in Govan Mbeki Avenue [the main street in the CBD of Port Elizabeth]."

"As teenagers we still have to cope with violence in the streets."

"Violence has also featured in my friends being robbed and mugged."

"In my community violence was everyday life; if we never heard gunshots before we went to bed, we had to start worrying because we thought something worse would happen like burglary or bombing of cars."

The following quotations represent the voice that emerged from the narratives that point to participants' perception of racism as a form of violence:

"I think the most common violence that I see everyday is people talking bad things about each other. Racism especially because I am Chinese and now living in a far away different place."

"Like my friend and his dad, they hate all blacks, they are racists. They purposely hit any black walking by his car. He also swears at them for no reason."

Graham-Bermann (in Holden, Geffner \& Jouriles, 1998:24) postulates that, besides the risks posed by exposure to media violence, society's tolerance of abusers, and the lack of community response when violence does occur, racism poses an additional social stressor. This perception is particularly relevant within the South African context with the specific historical challenges of race relations (compare also Mullender et al., 2002:138-139).

The focus of the article will now turn to a presentation of the second sub-theme induced during the process of data analysis, namely, youths' perception that violence occurs in an unclear normative space.

\section{Sub-theme 2: Violence occurs in an unclear normative space}

A fundamental question that seemed to emerge generally for the participants (and for me) was: what situations can be considered as "severe" enough to warrant intervention in whatever form? Wiehe (1997:162) alludes to the fact that no criteria are absolute (either-or) but rather that there are many shades of grey (cf. also Nielsen, 1996:133). In reflecting on this question, I became aware that it would appear to suggest that some abuse is regarded as normative. However, the pervading sense is one of the dilemmas about when one draws the line and takes action when (and if) we acknowledge that all relationships have the potential for abuse? In 
other words, where are the boundaries in the relationship space? (compare also Edleson \& Tolman, 1992:5). This links also to the context in which the youths live and are reared. The narratives of the youths seem to suggest that they are receiving mixed or unclear messages about what can be considered "acceptable" or normative in the context of interpersonal relationships. This engenders a sense of helplessness and confusion, which is poignantly articulated by one of the participants:

"We teenagers experience violence everyday but we can't seem to distinguish what is violence. We never know if we should speak out or keep quiet; we seem to accept it naturally when we're not supposed to. We also don't know if there are serious or big crimes or types of violence."

\section{Sub-theme 3: Violence is perceived to be the result of unexpressed feelings}

The third sub-theme encompasses the perceptions expressed by youths that violence is associated with unexpressed feelings or emotions. Nettleton and Gustafson (2002:298) assert that feelings or emotions "are usually elicited by evaluating events that concern a person's important needs or goals". The inability to express one's feelings or emotions may result in frustration and, over time, escalate into anger. Berkowitz in Huesmann (1994:36) quotes Weiner's (1992) attribution theory analysis of emotions that "tells us that people are apt to become angry when they have had an unhappy experience that they attribute to someone or something external to themselves, who could have controlled what had happened". Bolton and Bolton (1987:169) attribute frustration in the context of domestic violence to the psychological anxiety and tension that grows out of the perpetrator's own insecurity. Such insecurities are often unacknowledged and therefore unexpressed. Bolton and Bolton (1987:167) maintain that the fact that "aggression can occur in response to frustration has been firmly established since the 1930s". However, this does not mean that it will occur, except if the situation is cognitively interpreted and assigned meaning that sees violence as an appropriate response. Another perspective offered by Strongman (2000:112) is that anger, as a discrete emotion, is usually categorised as negative as it is an integral part of aggression, hostility and violence. This is not to negate the fact that anger can serve positive functions for human beings in having a mobilising or energising effect. Secondly, anger prepares us for defence in order to protect us from threat.

Quoting from Averill (1982), Strongman suggests that, based on socio-cultural theory, "anger is about upholding accepted standards of conduct, perhaps unwittingly". The latter is especially relevant in the context of the current research study, as parents are perceived by the youth as resorting to beatings instead of expressing their feelings or emotions about the so-called "transgressions" of their children. It also is related to the aspect of "values" (or more specifically lack of clarity about values) that emerged as one of the perceived causes of violence.

Linking the views expressed by the youths to the writings of Strongman (2000:220) on the social constructionist theory of emotions, anger is viewed as being entirely socially constituted. This means that for human adults there are external and internal stimuli that are interpreted, and in turn this interpretation mediates between the stimuli and any emotional response that may ensue. (compare also Berlin, 2002:115.) The external stimuli thus can be linked to "transgressions" of youths that are deemed as being unacceptable in terms of social standards of conduct. The internal stimulus of emotion is related to cognitive processes (both conscious and unconscious) that affect how the emotion (feeling state) is expressed or acted out. Mohr and Fantuzzo (2000) and Davies (1999) highlight how past experiences are internalised and are in turn used to filter future experience. Another theoretical viewpoint concerning feelings or 
emotions is the phenomenological theory of De Rivera (1992), in which he refers to and distinguishes emotional climate, culture and atmosphere. De Rivera (1992:198) describes an emotional atmosphere as a collective, localised emotional response to a particular event, while an emotional culture is a more enduring and relatively stable part of the social structure and institutions of a society. Emotional climate is located between the two, and endures over a generation or two; it is also responsive to factors such as religion, politics, economics and so on.

The selected quotations below evince the link made by participants between the expressions (or rather non-expression) of feelings:

"I saw/see violence as an excuse for people to express their feelings for others in cruel, harmful, physical ways.”

“The person who's causing all this pain can't deal with their anger and have to take it out on someone else."

"Parents especially ignore their children or beat their children to take out their frustrations even if it's not the child's fault."

"I think my father has a big problem with dealing with his anger..."

\section{Sub-theme 4: Violence is perceived not as a solution but a senseless act}

The fourth sub-theme identified during the process of data analysis represents the perceptions of youths that violence is not a solution, but a senseless act that has serious consequences. The participants' narratives seemed to convey a sense of the futility of violence as a mechanism for dealing with conflict. A number of participants linked this sub-theme to the need for skills to deal with conflict more effectively. Cahn (1992:viii) intimates that the more one studies the area of interpersonal communication, especially in intimate relationships, the more one sees conflict or opportunities for conflict. Cahn (1992) acknowledges that conflict and disagreements are unavoidable in relationships and often bring out the worst in people. Quoting Gottman (1991), he also points to the beneficial role that conflict plays in relationships when the parties involved in the relationship deal with the conflict effectively. In their narratives participants expressed the view that violence is used as a means of dealing with disagreements, which is often senseless given the circumstances. They also voiced the opinion that they do not see violence as a solution, as they see the negative and extreme consequences that it has.

The following direct quotes from participants' narratives are illustrative of the opinion that "violence is not a solution but a senseless act":

"I think violence is the most damn method anyone can use to resolve conflict, because it solves nothing; the only thing it does it brings more problems like fear, sense of control, lack of expression and the lack of integrity."

"I believe that no one has the right to humiliate the other person because of their own insecurities. Violence is not an answer; it don't solve nothing."

"As I grow up I realise that violence doesn't solve anything but actually makes it worse."

"I saw many people getting beat up because of silly arguments."

"I think personally that it [violence] is unnecessary ..."

"I hate violence and it doesn't solve anything. It just leaves everything worse than it was in the first place."

"I think if we get in a fight we should talk about things without fighting."

"Violence is the worst ever thought that came across man's thoughts." 


\section{Sub-theme 5: Violence is perceived to be destroying the world}

A number of the study's participants expressed to the view that violence is destroying the world by leading to destruction of human life and through the impact that violent crime has on the economy of a country. The two categories represented in the narratives were labelled as follows: violence destroys people's lives; and violence destroys the economy of a country. The following quotations illustrate this sub-theme:

"I asked a few friends what they think about violence and here is what they had to say: 'Violence is tearing apart our nation'. Another friend of mine said that violence could be stopped if people think right and realise that they are ruining not only our country but our world."

"Why can't violence just disappear. It will make the world a better place and there would be a brighter future ahead of us."

"We are ensuring the destruction of ourselves, others and this planet."

\section{Category: Violence destroys people's lives}

Referring to the WHO World Report on Violence and Health, Krug, Dahlberg, Mercy, Zwi \& Lozano (2002:1083) estimate that "about 4400 people die every day (around the globe) because of intentional acts of self-directed, interpersonal, or collective violence". The authors state further "many thousands more are injured or suffer other non-fatal health consequences as a result of being the victim or witness to acts of violence". This report notes that, besides the human costs and the impact on individuals and families, there are the more tangible financial costs of treating victims, supporting families, prosecuting perpetrators, the loss of productivity and investment, to name but a few.

A report entitled Costs of Intimate Partner Violence Against Women in the United States (March, 2003) makes reference to the human and economic costs of intimate partner violence (IPV) as being both direct and indirect. The study estimated that in the USA IPV costs nearly $\$ 5.8$ billion each year. The researchers acknowledge that this is probably an underestimation, given the incompleteness of data in some components. If we turn our attention to the human costs of violence, we become aware that violence results in psychological trauma, physical injury and sometimes death (Gelles, 1997; Kernic, Wolf \& Holt, 2000).

Brinegar (1992:34) introduces another dimension to the discussion of the role of violence in destroying people's lives, namely that of power. This links to a sub-theme that will be discussed later, namely the perception expressed by participants that 'violence has a gender and a power bias'. At this point, it is sufficient to raise the opinion expressed by Brinegar that "exploitive power assumes violence as a solution and victims as non-persons. It is a powerful force that destroys human life indiscriminately".

The following selected quotations make reference to the ways in which participants perceive violence as destroying people's lives:

"In South Africa there are people who had died as a result of the violences in their relationships. There are cripples who cannot go anywhere or do anything for themselves."

"In our black neighbourhoods we see these things happening in reality like killing each other."

"Violence is what destroys people's lives."

"You know what happen to my friend he kill another person over an argument in a shebeen."

"It scars people for life." 
"Violence is what destroys people's lives. It is what kills our brothers and sisters throughout the world."

\section{Category: Violence affects the economy of a country}

Such costs as highlighted above impact both directly on the economy of a country and its ability to sustain and support networks (for example, in the form of health care and mental health services) to its citizens (Krug et al., 2002:1083; Tjaden, Thoennes \& Allison, 2000:45). The threat of violence and the manifestation of violent crime and the concomitant safety fears have a negative impact on economic investment and tourism. The latter is especially relevant within the context of a developing economy as is characteristic of South Africa with its reliance on the tourism industry.

The following excerpts represent the participants' views on how violence affects the economy:

"Gathering around together in groups, they [reference to street children who engage in violent crime] are seen as a nuisance, frightening customers and tourists away from shopping centres."

"Violence is what destroys people's lives and the country's wealth."

"Violence is an embarrassment to our country."

\section{Sub-theme 6: Violence is perceived as having a gender and a power bias}

The narratives appeared to suggest that participants hold the perception that generally crime affects us all as citizens, both male and female, but their stories suggest that perpetrators of violence are predominantly male and or persons with power. For this reason the sixth subtheme "violence has a gender and a power bias" was derived. The Concise Oxford Dictionary (1995) defines "gender" as: "the grammatical classification of nouns and related words, roughly corresponding to the two sexes and sexlessness". Gerdes et al. (1988:122) define "gender" as "a somewhat broader term than the word 'sex" and refers to the individual's personal, psychological experience of being male or female". Edleson and Tolman (1992:19) have defined "power" in the domain of relationships as "the ability of one partner to potentially or actually modify the behaviour of the other when a conflict exists. It is the ability of one person to gain disproportionate access to resources that determine the direction of the lives of the people in the relationship or family".

In the context of the analysis of the content of the participant narratives, youths expressed the perceptions that, in the relationship domain, men believe that they own women and treat them as possessions; women tend to take the blame for the violence; and women provoke the violence. These views were identified as the categories that support the sub-theme, namely "violence has a gender and a power bias". The literature supports these perceptions of the youths and indicates that women are much more likely than men to suffer physical and probably psychological injuries from IPV (Gelles, 1997; Rand \& Strom, 1997; Tjaden, Thoennes \& Allison, 2000; Rennison \& Planty, 2003).

Power and gender are often factors that are ignored or minimised in ecological frameworks. According to Edleson and Tolman (1992:20), ecological frameworks focus on reciprocal transactions between two or more systems - yet factors such as gender and power are integral to the development of the individual's meaning system or chronosystem. The aforementioned authors assert that to ignore the factors of gender and power is indicative of "context stripping" or "microsystemic myopia". Feminist theorists have offered power imbalance as the basis upon which marital or domestic violence and sexual abuse are built (Bolton \& Bolton, 1987:165). 
For the majority of the participants there was a clear perception expressed that females are more likely to be victims of violence in the relationship sphere than males. Linking to the earlier discussion, the youths tended also to cast males in the character of perpetrator of violent crime. However, when one followed the trend in the narratives concerning abuse perpetrated on children, both parents appeared to be featured as perpetrators in the family or home environment. Youth also appeared to hold their mothers more accountable or responsible for their perceived choice to remain in violent relationships.

The following direct quotations reflect the notion of the gender bias of violence as perceived by participants:

"Most of the time women are victims of violence."

"Our ladies and sometimes young girls have to deal with sexual violence."

"Women are the most people who are the victims of these violences."

"Daar is 'n gesegde: All a girl can depend on is the daddy. Nie in hierdie werêld O-Nee! Hulle is die wat die meeste hulle vrouens en kinders mishandel."

"A man who lifts his hand up to a woman is a scumbag."

"They feel dependent on their spouses and that is why their spouses are abusing them, they think they have no place to go or anything to do without them."

"And I just want to say that men who beat women are cowards and men who rape are not real men."

"Geweld gebeur meeste van die tyd in getroude huwelike, waar mans hulle vrouens slaan of selfs dood maak. Ek sal se dit gebeur omdat mans nie hulle humeer kan hou nie dis wat hulle probleem is. Jy kry ook soms vrouens wat hulle mans slaan wat baie selde voorkom."

"I think in general boys are more violent..."

Relating to the "power bias of violence", the youths expressed the perception that violence is perpetrated as a show of power or to assert authority by "the strong over the weak", adults over children, or when one does not get one's way, one has to dominate in order to enforce one's will to control the situation. Analysis of the data seemed to indicate a subtle distinction between misuses of authority or power, for example, by a parent to a child, and a situation where violence is an assertion of power (domination); and situations of war where violence is rationalised as being "necessary" or justifiable. The following quotation alerts the reader to an excerpt from a narrative where corporal punishment is deemed to be unjustified:

"Violence started in my life since before I can even remember. I used to get a lot of hiding from both my parents for the silliest things imaginable."

The following quotes were gleaned From the narratives to further represent this aspect of the sub-theme:

"Most people would claim to be against violence but there are occasions when violence might be considered acceptable. Public opinion has frequently supported a country going to war."

"However, many people believe that it is justifiable to fight for a cause that they think is important."

The aforementioned data place the emphasis on the perception of the participants who perceive violence as having different standards, depending on where power or authority lies and the specific context. Earlier in the discussion on media violence, the structural connections of violence were alluded to as well as the mixed messages that society sends out about the 
132

condoning of violence in certain situations, for example, war. Given the fact that, for the participants, the war in Iraq was part of the temporal landscape of the day, it is thus hardly surprising that they would reflect this as one of the dominant discourses within society at the particular point in history.

In the next section the focus moves to a discussion of the categories that emerged from the data as they were interpreted to support the sub-theme of "violence has a gender and a power bias": men treat women as possessions; women tend to take the blame for the violence; violence is about control; and women provoke the violence.

\section{Category: Men treat women as possessions}

Kemp (1998:23) suggests that this view is consistent with feminist theory, which holds that patriarchy is the key factor in the abuse of women. The author quotes Christiansen, an Adlerian family therapist, who put forward the suggestion that "the hierarchical, maledominated family system that has developed out of the European tradition creates the cultural climate in which children and women can be abused". Such socio-cultural factors that impact on violence against women are highlighted in the South African context by Schoeman and Ferreira (2001:283) as sexism, gender role-stereotyping and norms relating to marriage and the family. The authors emphasise that such factors permeate our culture as well maintain social structure.

Sexism refers to the acceptance of one gender (males) as superior to the other (Schoeman \& Ferreira, 2001:284). Gender stereotyping or sex role arrangements (McNeece \& DiNitto, 1994:218) can be oppressive and cannot be divorced from the social forces that influence the family. Schoeman and Ferreira (2001:285, 287) assert that sexism and gender stereotyping have resulted in a type of compulsive masculinity; a protection of male authority; emphasis on women's role as wife; negative self-evaluation or self-judgment by women; and the perception that women should be treated as children. On a structural level such stereotyping dominates religious perspectives and also permeates the justice system. This also impacts on the way that individuals develop their gender identity.

These nuances are represented in the following quotations from participant narratives:

"They [men] think they are their gods. They make them [women] their slaves."

"My opinion is that guys think they own younger women's lives. It makes me sick."

\section{Category: Youths perceive that women tend to take the blame for the violence}

Self-blame as a feature of relationship violence is a dynamic that has been highlighted in the literature (Resick, 2001:69.) This view was expressed in the following quotation:

"Girls are always taking up blame, because us girls are always saying I was the one who started it and made him angry."

\section{Category: Violence is perceived to be about control}

Becvar and Becvar (2000:241) quote the theorists Haley and Bateson, who hold differing views on the phenomenon of control. According to Haley (1963), communication sequences and symptoms in family patterns are attempts to influence or control. In contrast, Bateson (1972) maintains that the issue of wanting control, or the illusion that control is possible, keeps human beings engaged in ecologically and interpersonally destructive behaviour. Berg-Cross (2000:329) adds the view that "control attempts at conflict resolution occur when one person attempts to get another person to do as he or she wishes by inducements or threats". 
The views expressed above appear to be similar to the perceptions voiced by participants. These positions are evident in the manner in which violence is viewed as a strategy for conflict resolution. Secondly, participants appeared to echo the stance adopted by Bateson (1972), when they allude to the fact that "violence is not a solution" as discussed in an earlier subtheme. The following quotations were selected as illustrative of the participants' perceptions:

"People pick on others for power they want to prove to other that they are in control and powerful and when they feel they are losing with words or other mechanisms they will turn to violence. The weaker person will do anything to avoid conflict because it may result in violence, including telling a lie."

"It just eats me that some people just allow themselves to be dominated and abused by someone."

"Violence has to do with lack of control when you feel you've lost control over yourself or someone else you will then turn to violence."

"I hate those power hungry people why control everyone else when you can control your world and if you can't you probably try and control everyone elses."

"I just don't get it why people use violence to get what they want."

\section{Category: Women are perceived to provoke the violence}

A number of the participants expressed the perception that, at times, women appear to provoke the violence. The literature reflects two points of view in this regard. The first view is that this can be seen as evidence of victim-blaming (Kemp, 1998:4-5; Prilleltensky et al., 2001:127). The second view is that encapsulated in the "cycle of violence" theory as posited by Walker (1979). Walker postulates that women reported provoking their abusers, at times, in order to accelerate the "resolution" of the cycle. Crosson-Tower (1999:103) concurs with this latter view and adds that the dynamic underlying the provoking of abuse can be equated with the need to be in control.

The quotations that reflect the perception expressed by participants that women provoke violence are:

"He [reference made to the stepfather of the participant] was about to throw my mother out of the window. My mother shouted at him "I don't care, do what you want to do". At that time we lived in a double-storey house."

"My uncle said she asked for it because he's tired and she's nagging on his head."

“... sometimes a woman is behind the violence."

"When the wife eventually swears enough and criticizes him and his family enough, the husband responds by grabbing her and shaking her. [Referring to the parents of a friend]. The wife edges him on and on until he eventually loses control."

\section{CLOSING REMARKS}

In drawing this article to a close the author presents a central storyline from the findings that emerged from the youths' narratives which represent perceptions articulated by the youths themselves. From the above discussion, it would appear that youths' perceptions of violence in relationships are the result of direct experiences either as victims or as witnesses of violence, or vicariously through the experiences of others with whom they are in relationships, for instance, peers, acquaintances and family members. Such direct and vicarious experiences leave youths with the perceptions that violence is part of the tapestry of everyday life; that violence destroys lives and the economy of the country; violence has a gender and power bias; that violence is not 
a solution but a senseless act and that it is the result of unexpressed feelings. From the narratives, it also emerged that youths are unsure of boundaries in relation to violence because they are often confronted with ambiguities, contradictions or conflicting messages about violence in relationships. The sites identified by youth where violence is perpetrated include the following: the family/home environment, the school, dating relationships and the community. The factors placed in a central position for the youths are the role of the media in portraying violence, which the youths perceive as "promoting" the idea that violence is an option for resolving conflicts.

In conclusion, at least three main observations emerge for consideration in relationship violence prevention programmes. First, it becomes apparent that the youth's narratives provide useful insight into the perceptions of the youths and as such provide important directional markers for intervention strategies that seek to address the reduction violence through relationship violence prevention with youths. The perceptions articulated by youths indicate the following areas for intervention:

- Firstly, relationship management skills in general and, more specifically, constructive conflict-resolution skills;

- Secondly, the youths' narratives suggest the need to challenge perceptions of gender role biases and stereotypes;

- Thirdly, prevention efforts should facilitate a process whereby youths are able to make sense of constructive negotiation of the ambiguities inherent in violence within relationship spaces.

The challenge to professionals is to take the perceptions of the youths seriously and to use these perspectives to develop effective programmes for relationship violence prevention.

\section{REFERENCES}

AFRICAN CHARTER ON THE RIGHTS AND WELFARE OF THE CHILD. 1990. Organisation of African Unity Document CAB/LEG/24.9/49 (1990).

BECVAR, D.S. \& BECVAR, R.J. 2000. Family therapy: A systemic integration. Needham Heights, MA: Allyn \& Bacon.

BERG-CROSS, L. 2000. Basic concepts in family therapy: An introductory text. New York: The Haworth Press.

BERKOWITZ, L. 1993. Aggression: Its causes, consequences, and control. New York: McGraw-Hill Book Company.

BERLIN, S.B. 2002. Clinical social work practice. New York: Oxford University Press.

BERTHOLD, S. 2000. War traumas and community violence: psychological, behavioural, and academic outcomes amongst Khmer refugee adolescents. Journal of Multicultural Social Work, 8(1/2):15-46.

BEZUIDENHOUT, C. \& JOUBERT, S. (eds) 2003. Child and youth misbehaviour in South Africa. Pretoria: Van Schaik Publishers.

BOLTON, F.G. \& BOLTON, S.P. 1987. Working with violent families. Newbury Park, CA: Sage Publications.

BRANTS, K., HERMES, J. \& VAN ZOONEN, L. 1998. The media in question. London: Sage Publications. 
BRINEGAR, J.L. 1992. Breaking free from domestic violence. Minnesota: Hazelden.

BURTON, J. 1997. Violence explained. Manchester: Manchester University Press.

CAHN, D.D. 1992. Conflict in intimate relationships. New York: Guilford Press.

COLLIER'S DICTIONARY. 1977. ( $2^{\text {nd }}$ ed) New York: Macmillan Publishing Company Inc.

CONCISE OXFORD DICTIONARY. 1995. $\left(9^{\text {th }}\right.$ ed $)$ Oxford: Clarendon Press.

COSTS OF INTIMATE PARTNER VIOLENCE AGAINST WOMEN IN THE UNITED STATES. March, 2003. Atlanta, Georgia: Department of Health and Human Services, Centres for Disease Control and Prevention; National Centre for Injury Prevention and Control.

CRABTREE, B.F. \& MILLER, W.L. 1999. Doing qualitative research $\left(2^{\text {nd }} e d\right)$. Thousand Oaks, CA: Sage Publications.

CRAWFORD, C. 1994. No safe place: the legacy of family violence. New York: Station Hill Press.

CRESWELL, J.W. 1998. Qualitative inquiry and research design: Choosing among five traditions. Thousand Oaks, CA: Sage Publications.

CROSSON-TOWER, C. 1999. Understanding child abuse and neglect. Boston: Allyn \& Bacon.

DAVIES, D. 1999. Child development: a practitioner's guide. New York: The Guilford Press.

DAVIES, P.T., HAROLD, G.T., GOEKE-MOREY, M.C. \& CUMMINGS, E. 2002. Child emotional security and interparental conflict. Monographs of the Society for Research in Child Development, 67(3):51.

DAVIES, P.T., HAROLD, G.T., GOEKE-MOREY, M.C., CUMMINGS, E., SHELTON, K. \& RASI, J.A. 2002. Relations between interparental conflict, child emotional security and social learning processes. Monographs of the Society for Research in Child Development, 67(3):41-62.

DENZIN, N.K. \& LINCOLN, Y.S. (eds) 2003. The landscape of qualitative research: Theories and issues. Thousand Oaks, CA: Sage Publications.

DE RIVERA, J. 1992. Emotional climate: Social structure and emotional dynamics. In: STRONGMAN, K.T. (ed), International reviews of studies on emotion, 2:197-218. Chichester: Wiley.

DE VOS, A.S. (ed) 1998. Research at grass roots: A primer for the caring professions. Pretoria: J.L. van Schaik Publishers.

DICKSON-TETTEH, K. \& LADHA, S. 2000. Youth health. South African Health Review. Available: http://www.rhru.co.za. [Accessed: 26 July 2003].

EDLESON, J.L. \& TOLMAN, R.M. 1992. Intervention for men who batter: An ecological approach. Newbury Park, CA: Sage Publications.

FRANCE, T.M. 2000. The role of attachment as a protective factor in adolescent violent behaviour. Adolescent and Family Health, 1(1):40-57.

FROMM, E. 1977. The anatomy of human destructiveness. Harmondsworth: Penguin.

GELLES, R.J. 1997. Intimate violence in families $\left(3^{\text {rd }}\right.$ ed). Thousand Oaks, CA: Sage Publications. 
GERDES, L.C. (ed) 1988. The developing adult ( $2^{\text {nd }}$ ed). Durban: Butterworths.

GILBERT, P. 1994. Male violence: towards an integration. In: ARCHER, J. (ed) Male violence. London: Routledge.

GOLDSTEIN, A.P. 1994. The ecology of aggression. New York: Plenum Press.

GRINNELL, RM 1993. Social work research and evaluation $\left(4^{\text {th }} \mathrm{ed}\right)$. Itasca, Illinois: F.E. Peacock Publishers Inc.

GUNTHER, B. \& WOBER, M. 1988. Violence on television: What the viewers think. London \& Paris: John Libbey.

HOLDEN, G.W., GEFFNER, R. \& JOURILES, E.N. (eds) 1998. Children exposed to marital violence: Theory, research and applied issues. Washington: American Psychological Association.

HUESMANN, L.R. (ed) 1994. Aggressive behaviour: Current perspectives. New York \& London: Plenum Press.

KEMP, A. 1998. Abuse in the family. Pacific Grove, CA: Brooks/Cole Publishing Company.

KERNIC, M.A., WOLF, M.E. \& HOLT, V.L. 2000. Rates and relative risk of hospital admission among women in violent intimate partner relationships. American Journal of Public Health, 90(9):1416-1420.

KRUG, E., DAHLBERG, L., MERCY, J., ZWI, A. \& LOZANO, R. 2002. World Report on violence and health. http://www.who.int/violence_injury_prevention/ [Online] Accessed 16 July, 2003.

MARSHALL, C. \& ROSSMAN, G.B. 1999. Designing qualitative research ( $3^{\text {rd }}$ ed). Thousand Oaks, California: Sage Publications.

McNEECE, C.A. \& DiNITTO, D.M. 1994. Chemical dependency: A systems approach. Englewood Cliffs, New Jersey: Prentice-Hall Inc.

MCWHIRTER, J.J., MCWHIRTER, B.T., MCWHIRTER, A.M. \& MCWHIRTER, E.H. 2004. At-risk youth: a comprehensive response $\left(3^{\text {rd }} \mathrm{ed}\right)$. Pacific Grove, CA: Brooks/Cole Publishing Company.

MILLER, J. \& GLASSNER, B. 1997. The 'Inside' and the 'Outside': Finding realities in interviews. In: SILVERMAN, D. (ed). 1997. Qualitative research: Theory, method and practice. London: Sage Publications.

Millstein, S.G., PETERSEN, A.C. \& NiGHTINGAlE, E.O. (eds) 1993. Promoting the health of adolescents. New York \& Oxford: Oxford University Press.

MOHR, W.K. \& FANTUZZO, J.W. 2000. The neglected variable of physiology in domestic violence. Journal of Aggression, Maltreatment and Trauma, 3(1):69-84.

MUllender, A., HAGUE, I., KELLY, L., MALOS, E., \& REGAN, L. 2002. Children's perspectives on domestic violence. London: Sage Publications.

MURRAY, J.P. 1995. Children and television violence. Kansas Journal of Law and Public Policy, 4(3):7-14.

MUUSS, R.E. 1982. Theories of adolescence $\left(4^{\text {th }}\right.$ ed). New York: Random House.

NATIONAL YOUTH COMMISSION. 2000. National Youth Policy. Pretoria. 
NETTLETON, S. \& GUSTAFSON, U. (ed) 2002. The sociology of health and illness reader. Cambridge: Polity.

NIELSEN, L. 1996. Adolescence: A contemporary view ( $3^{\text {rd }}$ ed). Fort Worth: Harcourt Brace College Publishers.

OXFORD ADVANCED LEARNER'S DICTIONARY. 1995. (5 $5^{\text {th }}$ ed). Oxford: Oxford University Press.

PATTON, M.Q. 2002. Qualitative research and evaluation methods $\left(3^{\text {rd }} \mathrm{ed}\right)$. Thousand Oaks, California: Sage Publications.

POTTER, W.J. 1998. Media literacy. Thousand Oaks, California: Sage Publications.

PRILlELTENSKY, I., NELSON, G. \& PEIRSON, L. (eds) 2001. Promoting family wellness and preventing child maltreatment: Fundamentals for thinking and action. Toronto: University of Toronto Press.

RAND, M.R. \& STROM, K. 1997. Violence-related injuries treated in hospital emergency departments. Bureau of Justice Statistics Special Report, 1-11.

RENNISON, C. \& PLANTY, M. 2003. Nonlethal intimate partner violence: examining race, gender, and income patterns. Violence and Victims, 18(4):433-443.

RESEARCH RESOURCE CENTRE, CSIR. 2000. Research gaps in youth violence. Unpublished document. Pretoria: CSIR.

RESICK, P.A. 2001. Stress and trauma. East Sussex: Psychology Press.

ROBERTS, B. 2002. Biographical research. Buckingham: Open University Press.

SCHOEMAN, H.P. \& FERREIRA, S.B. 2001. Sosio-kulterele beïnvloeding ten opsigte van geweld teenoor vroue. Tydskrif vir Geesteswetenskappe, 41(34):283-299.

SCHWANDT, T.A. 2001. Dictionary of qualitative inquiry. Thousand Oaks, California: Sage Publications.

STILES, M.M. 2002. Witnessing domestic violence: the effect on children. American Family Physician, 66(11):2052-2057.

STRAUSS, A. \& CORBIN, J. 1998. Basics of qualitative research: techniques and procedures for developing grounded theory $\left(2^{\text {nd }}\right.$ ed). Thousand Oaks, California: Sage Publications.

STRONGMAN, K.T. 2000. The psychology of emotion: theories, of emotion in perspective $\left(4^{\text {th }}\right.$ ed). New York: John Wiley \& Sons.

SWEATT, L., HARDING, C.G., KNIGHT-LYNN, L., RASHEED, S. \& CARTER, P. 2002. Talking about the silent fear: Adolescents' experiences of violence in an urban high-rise community. Adolescence, 37(145):109-122.

TERRE BLANCHE, M. \& DURRHEIM, K. (eds) 1999. Research in practice: applied methods for the social sciences. Cape Town: University of Cape Town Press.

TJADEN, P., THOENNES, N. \& ALLISON, C.J. 2000. Comparing stalking victimization from legal and victim perspectives. Violence and Victims, 15 (1):7-22. 
138

UNITED NATIONS. Convention on the Rights of the Child. General Assembly Resolution 44/25, Annexure 44, UN Document A/44/49 (1989).

WALKER, L. 1979. The battered woman. New York: Harper \& Row.

WIEHE, V.R. 1997. Sibling abuse: hidden physical, emotional abuse, and sexual trauma ( $2^{\text {nd }}$ ed). Thousand Oaks, CA: Sage Publications.

Dr Blanche Pretorius, Department of Social Development Professions, Nelson Mandela Metropolitan University; Prof Susan Terblanche, Department of Social Work, University of Western Cape; Prof Lullu Tshiwula, Vice-Rector: Support and Development, University of Western Cape, Bellville, South Africa. 